\title{
Death: Symbol of Threshold for Spiritual Rebirth
}

\author{
Lee young-sook
}

\begin{abstract}
$<$ Abstract $>$
Jung said that the stubbornness of life and the attitude towards life in the second half should be different. In the first half of life, the attitude towards life is the period of widening oneself, aggressively challenging life, concentrating excessively in order to achieve social success, and in the latter half of life, unlike the direction of life in the first half. It takes time to listen to the sound of the unconscious, but the process is scary and painful enough to be expressed by death. The process of changing the attitude towards life in the second half is expressed as psychological abandonment and wandering, which requires efforts to develop the ability to dismantle and reorganize the old mental structure. It is only through the process of death that it is transformed into a new process of individualization. This article is about the reasons for starting the process of death, looking at the cultural, religious, mythological, psychological, and creative meanings of death, and about the changes in the attitude towards life after death and suffering.
\end{abstract}

Keywords : the first half of life, the second half of life, death, conversion, rebirth

* Chief, Eunhasu Childcare Center (skyrain0531@hanmail.net) 
Journal of Symbols \& Sandplay Therapy, Vol.8 No.1.

\section{Introduction}

Death is inevitable for all. Many have tried to uncover the secret behind death, but no one knows to date where it begins and ends. It is because no one comprehends what is actually behind death (Kim \& Sohn, 2007). Where do humans come from and where do they go? Although this is one of the most important questions for all mankind, no satisfying answers, even philosophical or religious ones, have been found. Perhaps this question is destined to linger with human existence for eternity, not requiring a concrete answer. No one know what happens to the soul of the dead after death (Lee, 2015). All tribes and religions question death, but the answers remain in the imagination. Despite different efforts to fathom death, it remains unfathomable and comes to everyone without discrimination. Hence the decision of how to accept death is to be made individually (Schopf, 2007).

Death is an end to everything we hold familiar. We fear that when death comes we will be plunged into something quite unknown, become lost in an unfamiliar environment or become someone totally different (Rinpoche, 1993/1999). One unchanging truth to all living things is that all will eventually meet their demise. As Easwaran (1981/2005) explained, the more we become obsessed with living, the greater the fear of death becomes. Life is a relative concept of death. Without death, the meaning of life cannot be understood. Life is not separated from death; life is a journey, from the matrix to the grave. Jung asserted that our attitudes in the first half of life and the second half of life should be different. The first half of life is a period of ego-centering, which is finalized in puberty. In this period centroversion expresses itself as a compensatory relations between the conscious and the unconscious systems, but remains unconscious; in other words, the central organ of centroversion, the ego, has no knowledge of its dependence upon the whole. During the second half of life, which is generally ushered in by a psychological change of personality in the middle age, there exist a growing awareness of centroversion in the ego. The individuation process may then be initiated, resulting in the constellation of the Self as the psychic center of wholeness, which no longer acts only unconsciously but is consciously experienced (Neumann, 2010). Human beings experience chaos at some point in their lives. How we accept that chaotic period will determine the direction of our later life. This study will look how the human conscious life experiences death, a realm of 
the unconscious, or the psychological meaning behind the spiritual rebirth. It will also explore the cultural, religious, and mythical meaning of death.

\section{$\Pi$. The meaning of death}

\section{Cultural Significance of Death}

Unlike humans, animals do not understand death. They only look upon the nearing death, but do not contemplate on it or cope with it. The reason why ancient Egyptians mummified bodies was because they believed in life after death and that the deceased will need their bodies when reincarnated. The Chinese believed death could be overcome by becoming a spiritual hermit. Eternal life has long been taught by religions such as Christianity. Ceremonies to commemorate the deceased are something only humans do (Jeong et al., 2005).

Religious beliefs as well as customs related to the end of life were different amongst the tribes of the Native Americans, but most believed that humans had at least two souls. One is free, able to leave the body when one dreams or is ill, but the other is physical, hence always remaining with the human body. The former soul enters the afterlife after death, but the latter soul dies with the human body or at least is tied to the body for an indefinite amount of time. The Navajos believed death was when the life-force that entered the human body at birth leaves the body. Humans feared such death because while the goodness of the deceased contributed to the balance and harmony of the universe, the evil nature stayed in the form of a ghost and exerted evil influence on the living (Larry, 2001). The following are the lyrics to a song of the Taos:

Today is good day to die

Every living thing is in harmony with me.

Every voice sings a chorus within me.

All beauty has come to rest in my eyes. 
Journal of Symbols \& Sandplay Therapy, Vol.8 No.1.

All bad thoughts have departed from me.

Today is a very good day to die.

My land is peaceful around me.

My fields have been turned for the last time.

My house is filled with laughter.

My children have come home.

Yes, today is a very good day to die.

(Wood, 1974/2016, p. 34)

Death and afterlife were considered sacred in ancient Egyptian society. Death was not the end but only a transitional phase, and damage to the body that would be reborn was not allowed. They embalmed the body to preserve it in its original form and buried it with funerary pottery so the body receives the protection of goddesses. Offerings were made to the deceased, and the name of the deceased was chanted to ensure an afterlife for the deceased, but that did not guarantee life after death. The soul of the deceased had to pass through judgment by the god Osiris, who weighed the good and evil of the heart. Afterlife was given only if goodness outweighed evil, but if evil was heavier, the soul faced absolute death (Francois et al., 2002). Egyptians regarded Osiris as the dead as he overcame death, brought upon him by his brother, with the help of his wife; Osirism played an important role in the funerary rituals of the Egyptian kings as well as individuals. New burial practices emerged, such as burying the deceased with various memorabilia goods, and burying people alive along with the deceased. "Osiris overcame death and created himself, and is the bearer of the secrets of creation, resurrection, and rebirth" (Neumann, 2010). Osiris was able to make himself whole again because he had two souls; he preserved himself, transformed, and overcame death; he is the bearer of the secret of creation, resurrection, and rebirth; he could transform lower power into higher power; and he simultaneously ruled over the world and the underworld (Neumann, 2010).

Korean folklore has Okhwang sangje (the king of heaven and earth), who is the greatest god of all of Iseung (world of the living), Jeoseung (world of the dead), the heaven and the earth. Okhwang sangje lives in a jade imperial palace and rules over gods and 
humans. There are ten gods of the underworld who judge the dead, Jeoseung Shi-wang, and of all of them, Yeomra is the supreme ruler. Jeoseung Chasa are messengers of Jeoseung Shi-wang; they bring the dead to the underworld. It is generally known that there are several Jeoseung Chasa, but they come to Iseung to reap the dead in a group of three. Jeoseung Chasa Hae Wonmaek, Iseung Chasa Yi Deokchun, and Yeomra Chasa Gangrim Doryeong are three messengers who appear most often in folklore. The three Chasas are also known as Jeoseung Samchasa. Goddess of Ogu leads the dead through the path to the underworld; this god was Princess Bari, the seventh daughter of King Ogu of the kingdom of Sam. She leads the souls of the dead with a falchion, trident, bells, and a fan, and so she is respected as the progenitor of shamans. According to the myth, the one who took care of Princess Bari after she was forsaken by her parents became the guardian of the path to the underworld, and had ownership over the food offered at the beginning of a traditional funeral procession. Everyone has a shed in the underworld in which offerings are collected every time the owner of the shed shows a good deed to someone during their lifetime. These sheds are protected by keepers named goji (Seo, 2004).

To the modern people, death is taught as a loss and an extinction, hence they deny death or live on with the fear posed by death. The mere mention of death is uncomfortable and regarded as ominous. They even see death as a state of taking a risk, a state of exhausting all rights, or a state with no worries. The souls of the modern people are dry as they regard the present life as everything. They live on, having lost the ultimate meaning of life, with no practical or reasonable belief about the afterlife. The gruesome result brought about by their denial of death is beyond their individual level. High priests of Tibet are concerned that the people who do not have a solid belief about the afterlife may create a society that obsesses over shortsighted results, with no consideration about the retributive justice of their actions (Rinpoche, 1993/1999). They fail to listen to their hearts, and believe that living a busy life is their ultimate goal. They do not listen to the unconscious in their pursuit for material things. It is indeed difficult to listen to our unconscious in the first half of life other than investing much time into achieving our goals.

Death is not the end, but the transition from life to death. In ancient times, people 
Journal of Symbols \& Sandplay Therapy, Vol.8 No.1.

believed that the deceased may see and feel, but cannot communicate with the living; thus they can see their own corpse but cannot talk to their family who are grieving their death. "Who is to know that spirits go, as they come without a trace. It is indeed a vain attempt." As these lyrics to a song say, there is no substance (Lee, 2015). To break all ties with the real world where the ego has willpower is very painful, and all deaths break all ties. It makes one look back on all the relationships that one valued and cherished. To break all ties may be the duty of the deceased, while ceremonies and funeral methods are for the living rather than the deceased (Barley, 1995/2001).

\section{Religious Significance of Death}

Jung believed that the birth of man implies significant meaning. He explained that while some people totally reject or ignore the idea that life will continue after death, the idea that life has an unlimited continuity beyond the present is meaningful and comforting for most people. Even an attempt to think about the afterlife was a human primordial demand; it is a heritage and the archetype of mankind from ancient times, bringing wholeness to our individual life (Lee, 2015).

Christianity preaches about the Second Coming of Jesus, where $\mathrm{He}$ will return to judge the living and the dead, and the doors to the Kingdom of Heaven will open and only those righteous in Him will be lifted to meet and always be with God. Christianity also separates the soul from the physical body, and believes that the soul does not perish along with the body. The belief of the immortality of the soul is connected to the idea of resurrection (Hale, 2005/2006). In Christianity, Jesus' death was a sacrifice to save the people; Christians join Jesus in death through baptism and believe they can be resurrected through Holy Communion. From the perspective of Christianity, Jesus' death already encompasses the death of the people, which enabled the people to overcome God's neglect resulting from their sins (Bowker, 2005).

In Buddhism, death is the phenomenon in which the soul leaves the body. The soul is believed to be eternal. The most basic definition of death in Buddhism is the disappearance of life, heat, and consciousness from the body and the failure of all its organs, at which point 
the physical body is separated from life. The soul that is resurrected may be reincarnated, which is a process of the deceased's unfinished Karma being concentrated into one place and transferred to a new, next-level Karma. There are split opinion within the Buddhist community: there are those who say everything perishes with death and those who argue that immortal souls linger after death.

Death is not the end in Hinduism as well. Death only causes the soul to leave the body, and the body is only an object that has lost a soul. Therefore, the soul of the deceased is comforted, and prayed to be able to fit into new clothes. The body is wrapped in new linens and decorated with flowers before heading to the crematorium. The living pray for the repose of the deceased, but they do not mourn too much. The soul of the deceased become an existence that helps the living (Lee, 1997). In Hinduism, the body must be cremated within ten days, during which the soul may return to the body if not cremated in time (http://pann.nate.com/talk/118547514).

\section{Mythical Significance of Death}

In Greek and Roman mythology, Erebus, the god of darkness, and Nyx, the goddess of the night, had a son, Thanatos, the god of death. Thanatos was the personification of death, and he assisted Hades, the god of the underworld, who was a heartless, cruel, and merciless god that divided life and death. Thanatos was the Grim Reaper, who would roam the world in his black cape and, under Hades' order, drag a human's soul down to the underground. His grip was so strong that no one except Hercules defeated him. This signifies that no human can refuse the summoning of the unconscious. No humans can disobey their own nature, and they must return to nature (Jo, 2005).

In Indian mythology, Brahma, the senior god, created this world and all that lives on it. He was infuriated to see the world so ill because of the souls of the dead humans that lingered on Earth after death. Brahma collected the anger in his heart and created fire, planning to burn everything on Earth. Shiva begged for him to look upon the living with loving eyes, and when the fire of anger in Brahma's heart extinguished, a beautiful maiden of death was created. Brahma ordered the maiden to kill everything, by which she was devastated 
Journal of Symbols \& Sandplay Therapy, Vol.8 No.1.

and cried. Her tears were collected to create all kinds of evil, such as illnesses, disposal, greed, tempers, ill nature, and apprehension, which all helped her do her job. These evils went to the humans first, and when their job was done, she would come around to collect them and take them to the underworld (Schopf, 2007/2008). The process of agony she had to go through to accept herself, an entity that causes death, is everybody's inevitable fate. How to build oneself and continue the path of individualization is each and everyone's problem and task. Humans expect the safety of their lives to be eternal, but the gods have given us only a limited amount of time, and that is why humans cling to life.

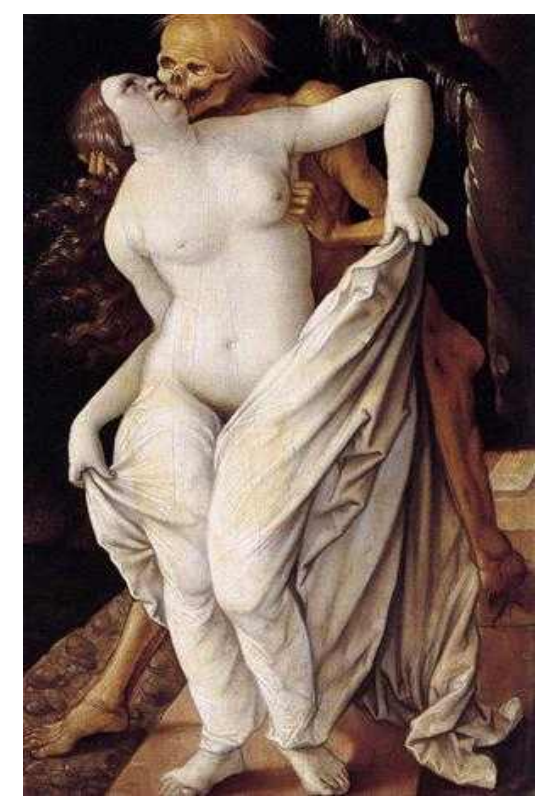

Figure 1. Death and the Maiden http://www.thruguide.com/?p=999

\section{The symbolism of death}

\section{Psychological Symbol of Death}

In alchemy, death is the stage of nigredo, or the stage of darkening. Death in 
religious asceticism represents "the overcoming of passions and desires through repentance, austerity, or inflicting torturous pain to the flesh.” Death in alchemy is associated with the most negative type of work, relating darkness, defeat, anguish, severance, death and decomposition. However, these negative images often usher in positive elements such as growth, resurrection and rebirth. In psychological terms, black represents the shadow. Black recognizes its shadow and its positive outcomes; the positive outcomes can be found in the principle of the opposites, for the black is the beginning of white. As Jung said, egocentricity is an indispensable element of the conscious. The death of the king or the sun in an archetypal level means that collectively overarching or dominant principles are to undergo a transformation and be born anew through death. A feeble old man represents that the once dominant consciousness and psychic principles that had lost their power and regressed to the domains of the dragon, the primal psyche; hence it must be transformed (Edinger, 2015). Black is an unpredictable darkness, representing the loss of consciousness, death, chaos, fear, and evil. Breaking away from the depression state of the black signifies the resurrection of a new life, and the ego goes back to the womb for rebirth and rejuvenation (Abt, 2005/2007). The state of black is a state of death, a unilateral flow of the conscious where the flow of the unconscious is blocked.

What cannot become black also cannot become white, as becoming black is the starting point of becoming white. Black is a signal for decomposition and alteration; it penetrates the flesh and destroys the tissues.

"You will slowly become quiet and change. Then you will discern that there is a stone growing in the bottle '-insofar as self-control, or non-indulgence, has become a habit, it is a stone "when that attitude becomes a fait accompli, the stone will be a diamond." (Edinger, 2015, p. 55).

What is death in terms of psychological symbols? The death of the conscious, or specifically the death of the conscious ego, is the state in which the functions of the ego-consciousness is suspended. The death of the ego is a state where in which one loses control over the ego-which causes a severe mental illness-and thus is dominated by the 
Journal of Symbols \& Sandplay Therapy, Vol.8 No.1.

unconscious (Lee, 2015). In such a case, one is not aware of the both sides of a situation; the person is one-sided, meaning that he or she is experiencing a psychological death. Lee (2013) explained that "the harmony between the opposites is suspended or lost" when one is psychologically dead. "The flow of psychic energy is blocked, and the suspension of such an energy results in death. Because one has exhausted all his energy for success in the outer world, he has lost the relationship with his inner world and his consciousness and unconsciousness are disconnected. In this state of death, one must listen to the voice of the inner world within the unconscious realm and return to the state of Chunghwajiki, or the balance between sky and the earth." Listening to our inner voices implies a personality integration, that is, the conscious and the unconscious are not disconnected but rather the conscious is paying attention to the voice of the unconscious. To this end, there must be a union of the opposites: the conscious and the unconscious, the ego and the Self, and the masculine and the feminine. There still exist a great gap between the death and life, and the world of death remains stronger than the world of life. "The meeting between Wife Chungjeong and Husband Dorang was not just a meeting between a woman and a man; it was a symbolic representation of the human nature to become whole through the union of this world and the other world, or of the conscious and the unconscious. The more the conscious pays attention to the unconscious and asks questions, the more the unconscious moves actively and gives proper responses. The exchange between the dead and the living is like the exchange between the unconscious and the conscious."(Lee, 2015).

The second half of life should be different from the first half of life. The growth of the conscious is possible only by experiencing death. Death and darkness are always with us, like companions (Ammann, 2001/2009). An active effort has to be made on the part of the ego-consciousness for the unconscious to engage in creative activities. By effort we are talking about the conscious attention to and interest in the unconscious. This change in attitude toward life will inevitably bring pain, but it is only through this process that we become whole. Centroversion, of which we were not aware of in the mid-stage of life, becomes conscious with the sudden change in personality, and hence the painful process in which the ego captures the whole of personality begins. Psychological transformations begin at the second 
half of life, through which life is expanded and integrated. This can be seen as the process of rebirth.

One of the key functions of dreams is compensation. When the wholeness is threatened due to one-sidedness toward the conscious, dreams alter and modify the skewed balance to achieve centroversion (Neumann, 2010). Dreams prepare the conscious not for the end of everything, but for profound transformations that are unimaginable via everyday, conscious means and also the continuity of the life process. Symbols that appear in such dreams are usually aligned with the theme or the structure of myths and religious beliefs relating to the post-mortal life. In such a case, mythological images play an important role. Psychologically, the underworld is a world beyond the conscious; in other words, it is the unconscious. The realm of the king of the underworld can be compared to the temenos (sanctuary), or the Self archetype, which exits deep in our inner world. It is the driving force behind self-realization. The road to self-realization is long and dangerous. In psychological terms, or in terms of the relations between the conscious and the unconscious, "the underworld" is a realm beyond "the world which we know." In other words, it symbolizes the unconscious. Stories about the underworld are about the unconscious. It is filled with contents that cannot be described with the word "projection" or "imagination" alone (Lee, 2015).

Jung believed that if there exist a continued life in the underworld, it would be that of the psyche because the psychic life requires neither time nor space. Jung explained that the existence of the underworld is a continual advancement in the world of images. The unconscious sends symbols of psychological transformation to the dreams of those who have developed a conscious attitude toward death. Dream is a signal sent by the unconscious to the conscious. The psyche is deeply involved in a form of existence without space and time (Lee, 2015). "A new conscious takes place after a psychological death; a new, brighter and expanded form of consciousness is created." We fear death, and that fear is a symbol of the sacred time period of pain and silence in which we reflect on ourselves in the unconscious realm. Mind is deeply involved in the form of being without space and time (Lee, 2015). "After a psychological death, a new consciousness takes place; a new, brighter and wider consciousness is created," and we fear death. It is also a symbol of the divine time of pain and silence that 
Journal of Symbols \& Sandplay Therapy, Vol.8 No.1.

insights itself into the world of the unconscious. In analytical psychology, the grave usually appears in various images related to suffering from guilt, spiritual death, internal anxiety and anguish. The grave, the skull, the angel of death, being crucified and bleeding as if suffering from an immense menstruation. All these are symbolic representations of the psychological condition a person experiences when he faces the darkness, when he has descended to the realm of the shadows, and experiences the death of his exiting conscious attitude (Ammann, 2001/2009).

\section{Symbolism of Death for Rebirth}

Humans cannot be reborn like deities. In the creative context, rebirth means psychological death rather than physical death, during which we may rearrange our inner world, i.e., to take apart the old psychic structure to rebuild or recreate it. The processes of disassembling old worldviews and life attitudes to reassemble them, or to willingly do away with the old form of life that acts as an obstacle to a new way of life, always brings fear (Ammann, 2001/2009). Death is the execution of something and represents change. The mysterien of death and the mysterien of reproduction shows death as some sort of transformation. To become a new being, one must go through symbolic death and take one's time for rebirth. This is the process of becoming "a new me" that is different from the old me (Oeri, 2014).

Death is an invisible attribute of life. Following death in this world, a spiritual renewal takes place. In initiation, we experience the darkness of death ahead of the birth of a new human being, resurrection, and reintegration. Death represents the change from one pattern of being to another; it is the reunion of the body, the earth, the soul and the spirit (Cooper, 2014). When a human being dies, his body becomes stiffened as he loses the energy from the balance between sky and the earth. In contrast, life means that the balance between sky and the earth is activated. The state in which the psychic energy flows endlessly is life. Death comes when that flow is blocked, stagnated, or suspended. Death is a state in which we become stiff and in an unnatural state, severed off from personality integration. The ego-consciousness has exhausted all the energy for the things in the outer world and thus lost 
its connection to the unconscious. The conscious must be regenerated through the unconscious, its matrix (Lee, 2013). Death is not the end but a transition, a period of pause. The will of life allows us to transcend death, travel through death, and venture out into a new world. A will for life is a prerequisite for a death as a continuous process. When the journey that goes through death begins will we be able to venture into the new world, where a new beginning, or rebirth, awaits us (Neumann, 2010).

Creativity refers to the ability to disassemble and reconfigure an old psychic structure. In order to live a new life, the attitude in the first half of life and the attitude in second half should be different. Life is where we dwell in temporarily, and during death we return to our home. We must be aware of the death within life, and the life within death, but they go unnoticed by many of us in modern society. Our life primarily focuses on living in the reality. Recognizing our conscious attitude in life can activate the power of creativity to look into our inner world (Lee, 2013). Just as the meaning of life can be grasped through death, it is possible to access human nature through life (Jo, 2005). However, we usually wait until our last moment to reflect on death (Rinpoche, 1993/1999). Amid running towards the goal in the outer reality, we lose sight of the goal and become lost once we rediscover the ego. It is at this juncture that we must look into the unconscious and listen to our inner voice.

\section{Symbolism of death in sandtray}

\section{Death in Sandpictures}

The client was a female in her fifties who has been suffering from depression because she has lost the meaning of her life as her children grew up. When her children became independent, she was confused about her role in life. Communication with her family was poor, especially with her husband as they were a long-distance couple.

In her 21st session, she talked about her attitude in life so far. She poured water in the sand and played with marbles. She then pushed all the marbles to one corner, placed a soft brain figure in the middle of the sandtray, and covered the brain with a water bucket. 
Journal of Symbols \& Sandplay Therapy, Vol.8 No.1.

She wound a thick, yellow snake around the bucket, and covered all of this with sand. The client surrounded that mound of sand with more snake figures, and made sure that the brain remained entirely invisible. The black snake is emerging from the mouth of the human face she created in the left rear corner where the mound of marbles is: the snake's tail is placed on top of the mouth and its head is heading toward the diagonal, opposite direction. On the other hand, the orientation of the yellow snake makes it look as if it is entering the mouth. After making this picture, she said the following while shedding tears:

"I don't want [it] to show."

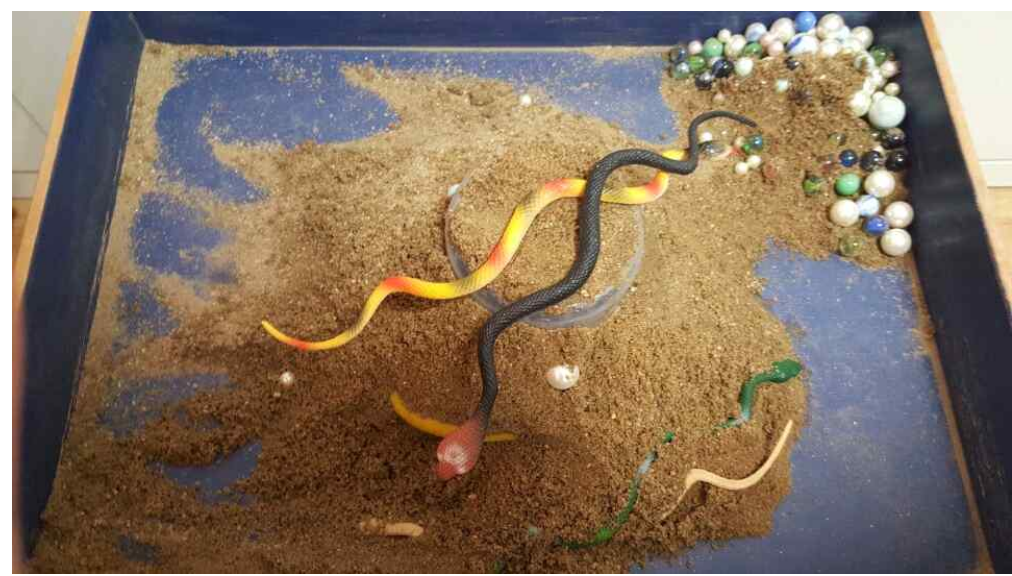

Figure 2. Sandpicture with a snake, session 21

Snakes are a medium that connects the heavens and the Earth and signify the transition from one state to the next (Adkinson, 2009/2015). Snakes that are poisonous cause death with a single bite, and are believed to have special transformation and magical powers, thus representing creation, reproduction, protection, and healing; the shedding of their skin is also seen as a representation of rebirth (Fontana, 2011). "Snakes that live underground are messengers of the underworld and can use the strength or magical power of the dead's omniscience. Snakes that belong to the underworld represent aggressive power of that realm and the dark gods. These snakes are guides of initiation, bring rejuvenation, are the symbol of the eruption of undifferentiated vitality that cannot be controlled as well as potential energy and spiritual activity, and are a warning of death" (Copper, 1978). 


\section{Rebirth in Sandpictures}

The client created Figure 3 during session 30. After crying for a while, she said, "I feel like something washed away." She reflected on her past self, someone who sacrificed so much for her family. She discovered the jewel in herself and started to realize that much wisdom was needed to protect it and that she was a very important being. The jewel represents spiritual enlightenment, purity, sophistication, advanced ability, and durability. It also holds the power of healing and magic, and thus represents psychological enlightenment (Tresidder, 2000/2007).

"[They] will protect [it] well."

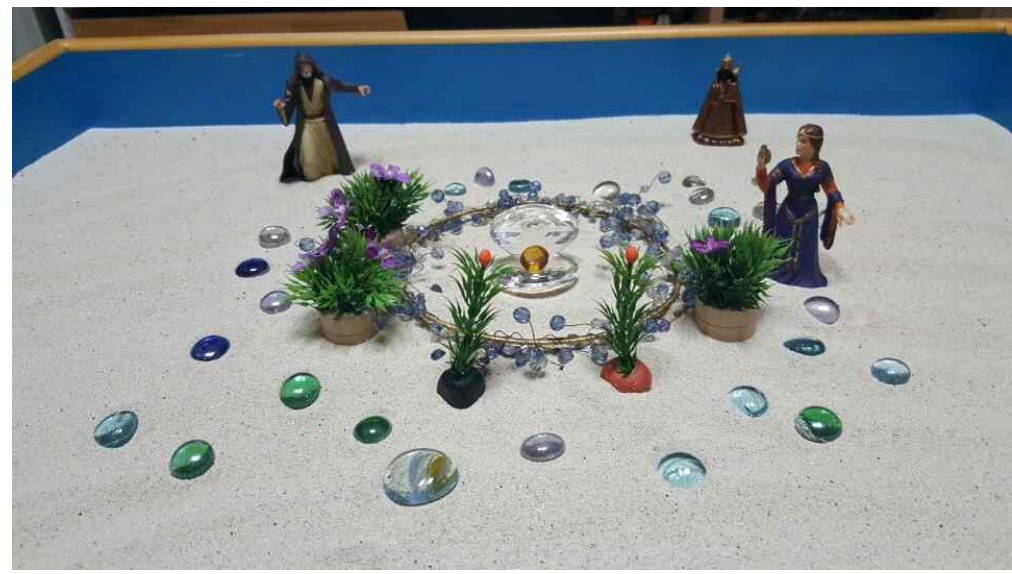

Figure 3. Sandpicture with a circle, session 30

The circle is the most natural and sacred shape. It is a universal symbol of wholeness, completeness, simultaneity, and the original completion. As the sun, it represents masculine strength, but as the spirit, heart, and the ocean that surrounds land, it represents Mother Nature, a feminine principle. It also represents the Ouroboros, the infinite circle of the beginning and the end (Cooper, 1978/1994). The black Maria figure in the right rear corner may be seen as representing the different aspects of the color black: the return to the womb or roots, preparation for a new birth, and acceptance of a new life, as well as depression, destruction, and death. Black may represent nature's destructive as well as regenerative aspects 
Journal of Symbols \& Sandplay Therapy, Vol.8 No.1.

in its initial stage, which is depicted in the Black Madonna figure. The blackhole of depression signifies the transition into the womb for the rebirth and rejuvenation of the ego (Abt, 2010). The seashells encompass symbolic death and resurrection; their form is like that of an impregnated woman, thus representing birth and rebirth (Mircea, 2005).

\section{Conclusion}

Jung asserted that psychological illnesses occur in the first half of life and in the second half of life for different reasons. The task for individuation in the first half of life is adaptation to society, whereas that in the second half of life is adaptation to one's inner world. In other words, while the task for individuation in the first half of life is strengthening the ego in order to adapt well to the social environment, the task for individuation in the second half of life is strengthening the Self to achieve self-realization. Therefore, psychological illness that occurs in the first half of life is related to the problem of social adaptation, or a weak ego. And in the second half of life, it is related to the problem of adapting to our inner world, or in other words, it is caused by deviating from the psychic wholeness.

In the first half of life, life is expanded towards a goal that is visible to our eyes. It appears that neuroticism arises when we take steps backward in life and cannot advance forward. In contrast, the latter half of life consists of gradually reducing that expansion of life while maintaining what has already been achieved. However, when we insist on maintaining the attitude of the first half of life, which no longer suits us, we experience neuroticism. Just as the patients of neuroticism in their first half of life are afraid of life, those in their second half of life are afraid of death (Lee, 2005). In life, there a progressive phase, where the psychic energy is oriented toward outside, and then there is the regressive phase, where the psychic energy is focused inside. By regressive we are not talking about our becoming sick or regressing back to childhood. The regressive phase is just as important as the progressive phase. Regression in indispensable for a new progression or advancement in life. The period of adolescence is considered as the progressive phase, whereas the period after middle age is when we ensure our inner stability. In this latter phase in life, we develop an interest in what we 
had neglected, and also become depressed or anxious. Jung explained that such phenomenon occurs before something new is created (Lee, 2014).

If we do not accept death while we are still living, we would have to pay a high price for our negligence, while living, at the time of death and after death. Without accepting death, our life will only be desolate and cannot be lived fully. Only after death will we be able to find our new selves (Rinpoche, 1993/1999). If the ego-consciousness is extremely one-sided, it reinforces the opposite nature repressed by the unconscious, which, at the point when the conscious' one-sidedness becomes extreme, engulfs the ego-consciousness like a tsunami. Hence the ego-consciousness is dominates by a nature that is precisely the opposite of its intentions (Lee, 2013). Everyone knows that he or she will die one day. As valuable as life is, the weight of death upon us is great. As a result, people become more obsessed with life, and try to find the value of their own. The delight in life could usher in a feeling of despair. The stronger we cling to life, the more desolate it becomes and leads us into the opposite direction.

"Why are we afraid of nothing-ness? Why do we become afraid of falling asleep?

Do we not sometimes want to be immersed in that nothing-ness, more than anything else?

There are those who claim they do not fear death.

Does that mean they do not know fear at all,

Avoid fear, or have overcome fear?"

- The Night by Ferdinand Hodler 1889 - (cited by Koo, p.36)

Death is a state in which our psychic integration is broken. It tells us that we do not have much time to live, and that we ought to gradually prepare for its coming. If we have been engaged in preparing for our living reality in the first half of life, we must begin to prepare for another part of life, which is death. The integration of the psyche is the most important element in the preparation for death (Kim, 2012), because pain of death is a prerequisite for the birth of a new being.

"Accepting the opposites at once is an experience that paralyzes us, to the degree of the crucifixion" (Edinger, 1985/2014). Death is sometimes experienced as failure and defeat, which we do not deliberately choose to experience. Regardless of my intentions, death comes 
Journal of Symbols \& Sandplay Therapy, Vol.8 No.1.

inside or us or from outside. This experience, however, is the beginning of the transformative process toward individualization. The hero gets his crown only after being abandoned, wandering, suffering, and risking death. Abandonment is an opportunity to understand the value of self-realization and accept it. Figure 4 is the sky seen from inside the grave. With the experience of the pain of death and consequentially with the rearrangement of the mind, the sky will not look the same as it did before.

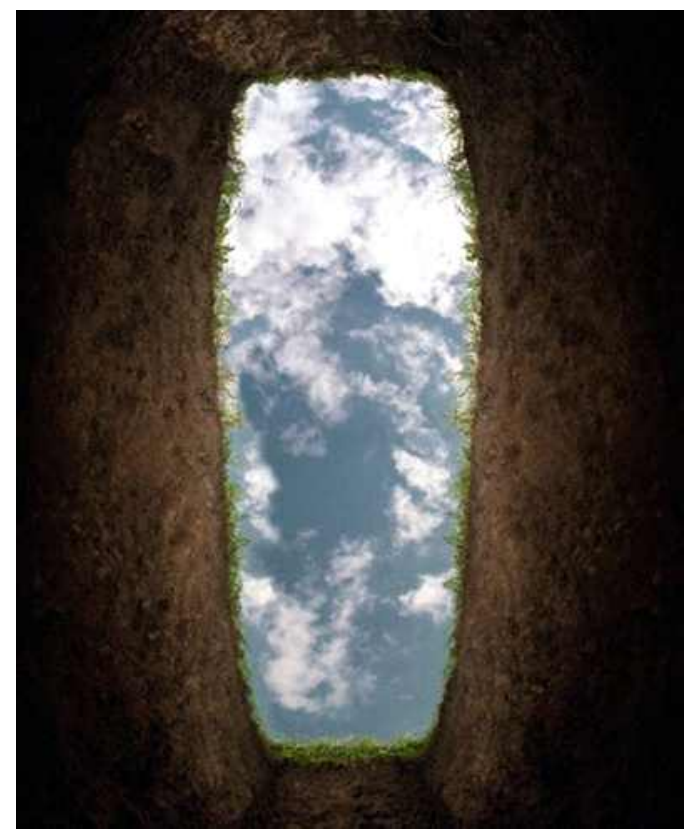

Figure 4. The View of the Sky from a Grave http://blog.daum.net/_blog/BlogTypeView.

\section{References}

Abt, T. (2005). Introduction to picture interpretation. Seoul: Analytical Psychology Center. (Trans. into Korea in 2007)

Ammann, R. (2001). Das sandspiel: Der Schöpherische weg der Persönlichkeitsentwicklung. Dusseldorf: Walter. (Trans. into Korean in 2009) 
Adkinson, R. (2009). Sacred symbols. Seoul: Sigma books. (Trans. into Korea in 2015)

Barley, N. (1995). Dancing on the grave: Encounters with death. Seoul: Yeamoon. (Trans. into Korea in 2001)

Birkhauser-Oeri, S. (2003). Die Mutter in Märchen. Fellbach: Bonz. (Tans. into Korean in 2007)

Bowker, J. (2005). The meanings of death. Seoul: Chungnyunsa. (Tans. into Korean in 2005)

Cooper, J. C. (1978). An illustrated encyclopedia of traditional symbols. New York: Thames \& Hudson. (Trans. Korean into 1994).

Easwaran, E. (1981). Dialogue with death. Seoul: Yemun. (Trans. into Korea in 2005)

Edinger, E. F. (1985). Anatomy of the psyche - Alchemical symbolism in psychotherapy. Boston: Open Court Publishing Company. (Trans. into Korea in 2014)

Francois, T., Lyon, D. A., \& Tomazo, R. (2002). La vie des au temps des oharaons. Seoul: Daehan publishing. (Trans. into Korean in 2005)

Fontana, D. (1993). The secret language of symbols. London: Duncan Baird. (Tans. into Korean in 1998)

Hale, D. R. (2005). Understanding christianity. Seoul: Utopia Books. (Tans. into Korean in 2006) Jeong, D., Kim, K., Jo, D., Kim, J., Paek, S., Park, C., Shin, O., Ahn, S., Lee, J., Park, W., \& Jeong, S. (2005). Death from a philosophical viewpoint. Seoul: Sanhae.

Jo, Y. (2005). Eros and Thanatos. Paju: Sallim.

Kim, S. (2012). Analytical psychology and christianity. Seoul: Hakjisa.

Kim, Y., \& Sohn, M. (2007). The folk culture of Jeju (2) 《Graves in Jeju》. Seoul: Shinkwang Sealing.

Koo, I. (2015). A philosophical study on death. Paju: Hangilsa.

Larry, J. Z. (2001). Native north America. Seoul: Changhae. (Trans. into Korea in 2001)

Lee, B. (2013). Laozi and Jung: An interpretation of Tao Te Ching from the view of analytical psychology. Paju: Hangilsa.

Lee, B. (2014). Analytical psychology. Seoul: Ilchokak.

Lee, B. (2015). Shamanism in Korea and analytical psychology. Paju: Hangilsa.

Lee, E. (1997). Understanding hinduism. Seoul: Sechang Publish.

Lee, J. (2005). Jung psychology and orientalism. Seoul: Hana Medical Publishing Company. 
Journal of Symbols \& Sandplay Therapy, Vol.8 No.1.

Mircea, E. (1952). Images et Symboles. Seoul: Kachi Publishing. (Trans. into Korea in 1998)

Neumann, E. (2004). Ursprungsgeschichte des Bewusstreins. Zurich: Clausen \& Bosse, Leck. (Trans. into Korea in 2007)

Rinpoche, S. (1993). The Tibetan book of living and dying. Seoul: Minumsa. (Trans. into Korea in 1999)

Schopf, S. (2007). Wie der Tod in die Welt kam. Seoul: Words \& Books. (Trans. into Korea in 2008)

Seo, J. (2004). Mythologies we should know. Seoul: Hyeonamsa.

Tresidder, J. (2000). Symbols and their meanings. Seoul: Duncan Baird Publishers. (Trans. into Korea in 2007)

Wood, N. (1974). Many winters. Seoul: RH Korea. (Trans into Korea in 2016)

http://blog.daum.net/_blog/BlogTypeView.do?blogid=0LkBS\&articleno=6935542

http://pann.nate.com/talk/118547514

http://www.thruguide.com/?p=999 